\title{
Trends in the Global Market for Freight Aircraft
}

\author{
M. M. Gyazova ${ }^{a, *}$ and M. V. Siluyanova ${ }^{a, * *}$ \\ ${ }^{a}$ Moscow Aviation Institute, Moscow, 125080 Russia \\ *e-mail:mgyazova@gmail.com \\ **e-mail:dc2mati@yandex.ru \\ Received January 18, 2021; revised January 18, 2021; accepted January 18, 2021
}

\begin{abstract}
Globally, national economies differ in levels of development, openness, and participation in international trade. Market saturation is accompanied by different levels of international trade. In addition, passenger and freight loads in air transportation are changing. On the other hand, economic principles are inadequately developed; and research on methodological principles regarding transportation and logistics is sparse. Those circumstances point to the need for analysis of the position, role, and significance of airfreight as an economic category.
\end{abstract}

Keywords: airfreight, global market, transport services, air transport, market development, specialized freight aircraft, cargo planes, transportation systems, logistics

DOI: $10.3103 / \mathrm{S} 1068798 \mathrm{X} 21070121$

By creating an innovative and dynamically developing civil aviation fleet and a balanced national airtransport system, Russia's economy may be stabilized and expanded, quality of life may be improved, and transport security may be ensured. That would provide competitive benefits for aircraft manufacturers and operators and consolidate their position in global markets. Airfreight is also known to stimulate the economies of developing nations since it connects markets on different continents.

According to data from the International Civil Aviation Organization (ICAO), a developed airfreight network provides long-term economic benefits associated with an overall increase in labor productivity [1]. New markets are opened; exports expand; and competition increases in the domestic market, with a broad selection of imported products. Over the last few decades, the role of civil aviation in the global economy has steadily expanded. According to information from the Boeing Corporation, international airfreight capacity has increased by $250 \%$ over the last twenty years, to 180 billion t-km. Of this total, $90 \%$ corresponds to regular airlines. Boeing predicts that international air transport will triple by 2029 , with a mean annual increase of $5.9 \%$ [2].

According to ICAO data, the direct annual economic impact of global civilian airfreight is more than $\$ 700$ billion. Each year, civil aviation carries more than 46 million $t$ of goods and mail, corresponding to a third of the freight exchange between regions. The world stock of commercial aircraft is more than 26500; each airplane can carry more than $9 \mathrm{t}$. The world has approximately 40000 civilian airports, of which more than 1000 serve international routes. Around $1400 \mathrm{reg}-$ ular routes are currently flown. Aviation represents about $8 \%$ of the world's gross domestic product (GDP)-around \$3 trillion. This impact is amplified by the multiplication effect on other sectors of the economy, which has only grown with the introduction of electronic commerce, currently amounting to $\$ 1.5$ trillion globally.

A key factor in developing a transportation system is to maximize the mobility in airspace. New airspace configurations require the development of improved aircraft capable of flight over complex trajectories in powerful air currents. The development of airfreight, the competitive environment, and business strategies may be analyzed on the basis of Porter's approach [3]. Porter outlines methods of creating competitive advantage and long-term profitability and also methods in which companies may maintain their long-term profitability and competitiveness. He notes five main considerations: the risk that new players will appear in the market; the risk that alternative services will appear; the influence of suppliers; the influence of customers (purchasers); and competition between market participants.

In terms of airfreight, those five categories are as follows.

(1) The risk of new players. Airfreight is governed by a complex system of regulations, which impede the appearance of new players in the market. In addition, new entrants must make major capital investments, since aircraft are expensive to acquire (leasing) and operate (maintenance). Thus, the barriers to new market players are high. 
(2) The risk of alternative services. Most freight may be transported by various means. For airfreight, alternatives include transportation by sea, road, and railroads.

(3) Influence of suppliers. Aviation is a service. Hence, customers are fundamental. In addition, services are immaterial; there are no raw materials to acquire. However, all aviation companies must buy spare parts and fuel. Given the specificity of the materials required, we may conclude that, thanks to the absence of competition between suppliers and the inability to substitute one material for another, suppliers have a considerable influence on the quality of aviation services. The basic suppliers are airports, which provide runways, ground crews and other staff, and so on. Aircraft operators also depend on fuel suppliers; fuel accounts for around a third of all transportation costs. The competitiveness of airfreight companies largely depends on relationships with airplane suppliers and maintenance providers. Today, the acquisition of new aircraft with high fuel efficiency confers considerable competitive benefits.

(4) The influence of customers (purchasers). The most influential customers are major shipping companies or expediters, which determine freight volumes, since they control the whole supply chain, selecting modes of transportation, routes, and carriers.

(5) Competition between market participants. Airfreight companies compete actively with one another, although competition differs by route and network. Globally, there are several groups of carriers.

Pricing and tariffs are important problems for air transportation, including airfreight carriers, on account of the specific features of the sector [4-6].

The sharp drop in demand for air transportation in response to the COVID-19 coronavirus outbreak has impacted the profitability of all the interested parties, including aviation companies, airports, aeronautical services, airplane manufacturers, and maintenance groups. According to ICAO estimates, the likely consequences of the global spread of COVID-19 and the consequent decrease in regular international passenger flights in 2020 (relative to forecasts) are as follows: (1) $37-78 \%$ decrease in available seats; (2) decrease in passengers by 550 million; (3) potential loss of $\$ 90-$ 118 billion in airlines' gross operating revenues.

The impact will be greatest in Europe and the Asian-Pacific region, followed by North America and the Middle East. For example, in that period, the airlines' loss of gross operating revenue on international passenger flights to and from China will be \$19.422.5 billion. According to ICAO estimates, civil aviation generated $\$ 136$ billion in tax revenue in 2019, thanks to passenger fees, value-added tax (VAT), cus- toms and immigration fees, etc. [7-9]. Thus, in view of the direct and indirect benefits provided by civil aviation, the state must work toward its restoration, so as to ensure an optimal balance of economic interests among the interested parties, including aviation companies, airports, aeronautical services, airplane manufacturers, and maintenance groups.

\section{CONCLUSIONS}

The restoration of the aviation industry after the COVID-19 crisis may require unprecedented measures, including state innovations. We may expect accelerated growth of electronic commerce, improvements in supply logistics, the appearance of more stable and controllable supply chains, the development of drone networks, increase in the number of small private aircraft, and diversification of major airlines, thanks to the creation of specialized airfreight subsidiaries. That will increase the demand for specialized cargo aircraft.

\section{REFERENCES}

1. ICAO Europe/North Atlantic Office: towards the recovery of the aviation industry after COVID-19 pandemic. https://favt.ru/public/materials//a/3/7/7/b/a377b4d60b 24bca8701b5e9e4ea8142c.pdf.

2. World air cargo forecast, 2018-2037. https://www.boeing.com/resources/boeingdotcom/commercial/aboutour-market/cargo-market-detail-wacf/download-report/ assets/pdfs/2018_WACF.pdf.

3. Porter, M.E., On Competition, Boston: Harvard Business School Press, 1998.

4. Kalugin, A.A., Kalugina, G.A., and Ryapukhin, A.V., Informational support for the sale of passenger aircraft, Russ. Eng. Res., 2021, vol. 41, no. 2, pp. 183-187.

5. Kraev, V.M., Tikhonov, A.I., and Novikov, S.V., Economic conversion in the aviation industry, Russ. Eng. Res., 2018, vol. 38, no. 4, pp. 330-333.

6. Tikhonov, A.I., Sazonov, A.A., and Novikov, S.V., Digital aviation industry in Russia, Russ. Eng. Res., 2019, vol. 39, no. 4, pp. 349-353.

7. Novikov, S.V., Conceptual analysis of aviation infrastructure, Russ. Eng. Res., 2019, vol. 39, no. 4, pp. 354356.

8. Burdina, A.A. and Bondarenko, A.V., Assessing the strategic efficiency of aviation projects, Russ. Eng. Res., 2020, vol. 40, no. 5, pp. 439-441.

9. Ermakova, O.V., Kaloshina, M.N., and Dianova, E.V., Management of innovative projects over the life cycle of distributed aviation systems, Russ. Eng. Res., 2019, vol. 39, no. 5, pp. 439-442.

Translated by B. Gilbert 